\title{
Helmet Noninvasive Mechanical Ventilation in Patients With Acute Postoperative Respiratory Failure
}

\author{
Francisco Javier Redondo Calvo MD PhD, Maria Madrazo MD PhD, Fernando Gilsanz MD PhD, \\ Rafael Uña MD PhD, Rubén Villazala MD, and Ginés Bernal MD
}

\begin{abstract}
BACKGROUND: The physiological and clinical effects of noninvasive ventilation (NIV) on acute postoperative respiratory failure are relatively unknown. The aim of this study was to determine the prediction factors for failure in the use of NIV with a helmet in this context. METHODS: This was a prospective observational study. The use of NIV was assessed for a period of 2 years in a postoperative ICU. Demographic data were collected, as well as acute respiratory failure (ARF) and arterial gas readings. Hemodynamic changes were assessed using pulse contour cardiac output technology, and the clinical development of subjects was recorded. All subjects who developed ARF were treated using NIV as their primary care, depending on whether the technique was successful or the subject required intubation. The risk factors that determined failure in the application of NIV were subsequently determined. RESULTS: Of the 99 subjects presenting with postoperative

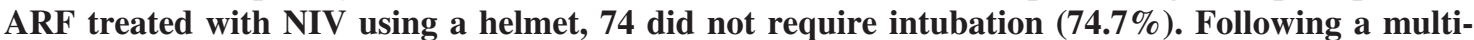
variate analysis using logistic regression, we determined that there are 3 independent risk factors for the failure of NIV. Three factors were associated with respiratory failure: ARDS, pneumonia, and lack of improvement with NIV in 1 hour (increase in the $\mathrm{P}_{\mathrm{aO}} \mathrm{O}_{2} / \mathrm{F}_{\mathrm{IO}_{2}}$ ). CONCLUSIONS: NIV using a helmet could provide an effective alternative to conventional ventilation in selected patients with postoperative ARF. Key words: noninvasive ventilation; helmet; acute postoperative respiratory failure; endotracheal intubation; ARDS; pneumonia. [Respir Care 2012;57(5):743-752. () 2012 Daedalus Enterprises]
\end{abstract}

\section{Introduction}

Acute respiratory failure (ARF) is a frequent complication in critical care units during the immediate postoperative phase of various types of surgery, and has a significant morbidity and mortality rate. ${ }^{1-3}$ It is most frequently encountered in the postoperative phase of abdominal sur-

\footnotetext{
Drs Redondo, Madrazo, Villazala, and Bernal are affiliated with the Department of Anesthesiology and Critical Care, Hospital General Universitario de Ciudad Real, Ciudad Real, Spain. Drs Gilsanz and Uña are affiliated with the Department of Anesthesiology and Critical Care, Hospital Universitario La Paz, Madrid, Spain.

The authors have disclosed no conflicts of interest.

Correspondence: Francisco Javier Redondo Calvo PhD MD, Department of Anesthesiology and Critical Care, Hospital General Ciudad Real, Ciudad Real 13005, Spain. E-mail: ardredondo@ hotmail.com.
}

DOI: $10.4187 /$ respcare. 01170 gery, where there is a reduction in respiratory volumes, elevation in both hemidiaphragms, and a tendency for the formation of basal atelectasis. ${ }^{4-8}$ When patients admitted to the resuscitation unit develop hypoxemic ARF in the postoperative phase, they tend to require endotracheal intubation and mechanical ventilation. These in themselves are prediction factors for in-hospital mortality. ${ }^{9-17}$

Unlike exacerbation of COPD ${ }^{18}$ and acute cardiogenic pulmonary edema, ${ }^{19}$ there are no prospective or controlled studies that demonstrate the effectiveness of noninvasive ventilation (NIV) in other causes of ARF. ${ }^{20-22}$ However, clinical experience suggests that it may have potential benefits, such as decreasing respiratory work and encouraging the exchange of gases in the alveoli, therefore improving the comfort of patients with respiratory failure.

When NIV is effective and a means of avoiding endotracheal intubation in ARF, the rate of morbidity and mortality associated with mechanical ventilation is reduced. ${ }^{18,19,23-25} \mathrm{~A}$ reduction in the number of infectious complications is the main advantage of NIV. ${ }^{26}$ NIV is safe, and just as effective as 
mechanical ventilation in improving gaseous exchange in patients with various patterns of ARF. 18-21,27-29

Numerous studies provide evidence of the selective application of NIV in ARF, in immunocompromised patients, ${ }^{21}$ and following thoracic surgery. ${ }^{27}$ Studies in the literature ${ }^{28,29}$ showing the results of the use of NIV in ARF in the context of postoperative care following abdominal surgery are few and far between. Clinical experience published to date on the matter of postoperative care following abdominal surgery is limited to the use of CPAP in a preventive capacity, and not as a form of treatment for ARF (therapeutic use). ${ }^{30-34}$

In an attempt to improve comfort and prevent complications arising from the use of interfaces available to date, the Antonelli group ${ }^{35}$ developed a helmet interface that would appear to reduce the need for intubation, while ensuring greater efficiency than the facial interface, since it is more easily tolerated and has fewer side effects and leaks less. The effectiveness of CPAP using a helmet, without the need for a ventilator, was recently described ${ }^{36}$ in a study of patients with acute cardiogenic pulmonary edema. It has been used in ARF with diverse etiologies such as acute pulmonary edema and respiratory distress syndrome. When compared with face masks, it has been found to present the same results, with few complications, while being better tolerated.

This prospective study was undertaken in light of the lack of studies in the literature involving the use of NIV in the postoperative care of patients having undergone various types of surgery with hypoxemic respiratory failure, and the potential advantages offered by the helmet interface. The aim of the study was to investigate prospectively outcome descriptors for NIV applied using a latex-free polyvinyl chloride transparent helmet, in postsurgical patients presenting with acute hypoxemic respiratory failure with varying forms of etiology, once they have been admitted to the resuscitation unit.

\section{Methods}

\section{Subjects}

For a period of 2 years, patients undergoing postoperative care following surgery, who developed acute hypoxemic respiratory failure, were recruited on a prospective basis at Hospital General de Ciudad Real, Ciudad Real, Spain. The study was approved by the ethics and research committees, respectively. Informed consent was obtained from all subjects, or the next of kin, included in the study.

The inclusion criteria were a $\mathrm{P}_{\mathrm{aO}} / \mathrm{F}_{\mathrm{IO}_{2}}$ of $<200 \mathrm{~mm} \mathrm{Hg}$ while breathing at least $10 \mathrm{~L} / \mathrm{min}$ oxygen, the presence of dyspnea, a respiratory rate $>25$ breaths $/ \mathrm{min}$, and contraction of the accessory inspiratory muscles or paradoxical

\section{QUICK LOOK}

\section{Current knowledge}

Indications for noninvasive ventilation (NIV) continue to expand. The helmet is one of the new interfaces to assist in the application of NIV.

\section{What this paper contributes to our knowledge}

In patients with postoperative respiratory failure, helmet NIV is associated with a reduced need for intubation. Failure of NIV is associated with failure to improve oxygenation within 1 hour, development of ARDS, and pneumonia.

abdominal motion (Fig. 1). Exclusion criteria were as follows: arterial oxygen saturation $<80 \%$ with maximal $\mathrm{F}_{\mathrm{IO}_{2}}$, arterial $\mathrm{pH}<7.30$ with $\mathrm{P}_{\mathrm{aCO}_{2}}>55 \mathrm{~mm} \mathrm{Hg}$, age $<18$ years, need for cardiopulmonary resuscitation, Glasgow coma score $<8$, systolic blood pressure $<80 \mathrm{~mm} \mathrm{Hg}$, evidence of myocardial ischemia on electrocardiogram, excessive secretions, inability to protect the airway, and active hemorrhage. Reasons for subject withdrawal from the study were intolerance of the interface, and subject or family wishes.

Pneumonia was defined as the presence of an infiltrate on chest radiograph, plus at least one of: purulent endotracheal aspirate; known pathogens on a Gram stain, or cultured from sputum or blood; temperature higher than $38.5^{\circ} \mathrm{C}$ or lower, leukocytes higher $12 \times 10^{3} / \mu \mathrm{L}$, or $20 \%$ immature forms. Criteria for atelectasis and ARDS followed consensus guidelines. ${ }^{37}$ Distinction between moderate and severe atelectasis was defined by reduced lung volume in the chest $\mathrm{x}$-ray and the computed tomographic scan. NIV was applied when flexible fiberoptic bronchoscopy did not get atelectasis reexpansion.

\section{Protocol for Application of NIV}

CPAP was generated using a flow generator with adjustable inspiratory oxygen fraction and applied using a latex-free polyvinyl chloride transparent helmet (CaStar, Starmed, Italy), at different pressure readings, generated by a flow meter that allowed high fluxes to be administered, with mixtures of $\mathrm{O}_{2}$ and air. The starting pressure was between 7 and $10 \mathrm{~cm} \mathrm{H}_{2} \mathrm{O}$, and this was increased in multiples of $2 \mathrm{~cm} \mathrm{H}_{2} \mathrm{O}$, according to the needs of the subject. (Fig. 2).

When assessing the response, arterial gas readings and clinical parameters determined at basal level were taken into account at 3 hours, 6 hours, 12 hours, 24 hours, and 48 hours during treatment with NIV and the removal of 


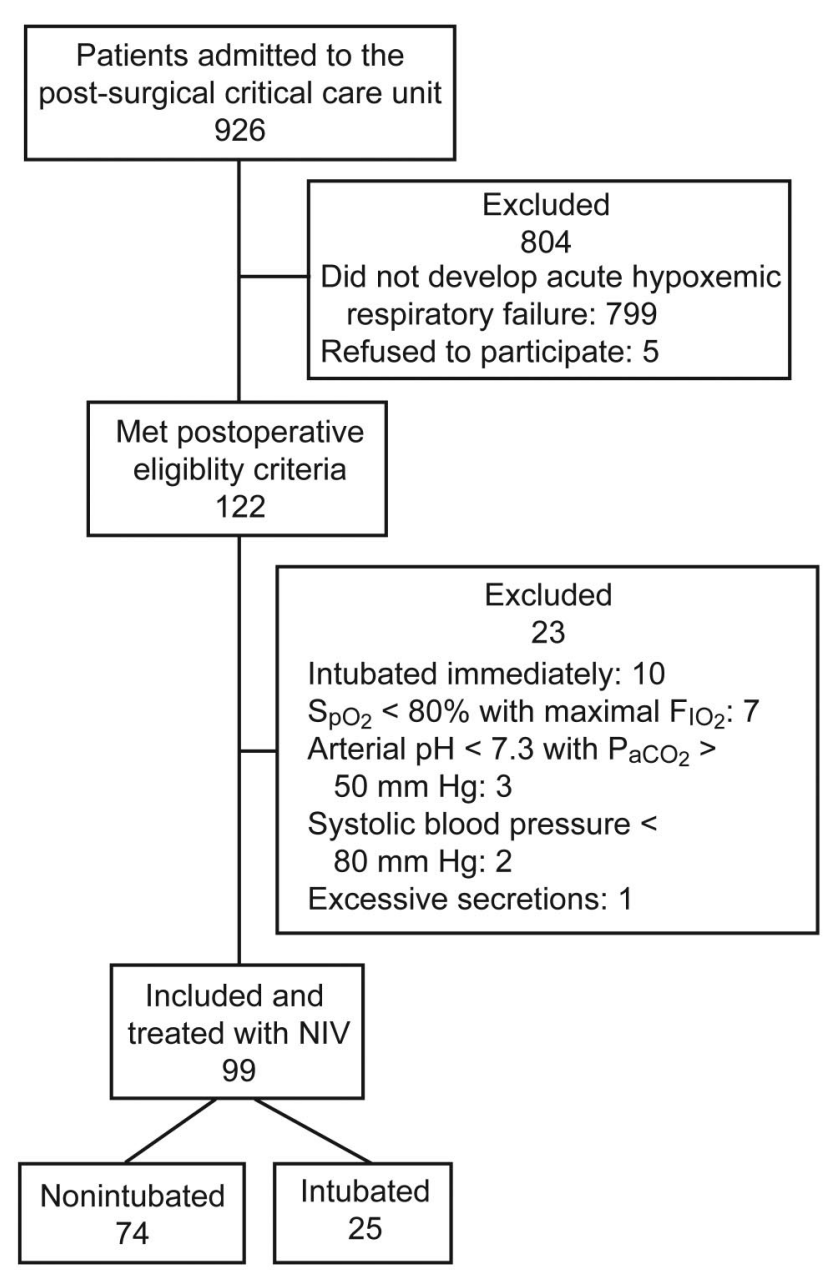

Fig. 1. Subject flow chart.

ventilation. Improvement in the exchange of gases is determined as the capacity to increase the oxygenation index $\left(\mathrm{P}_{\mathrm{aO}_{2}} / \mathrm{F}_{\mathrm{IO}_{2}}\right)$ to $>200 \mathrm{~mm} \mathrm{Hg}$, or an increase of this index of by $>100 \mathrm{~mm} \mathrm{Hg}$ over the base rate.

The criteria for intubation were as follows: inability to maintain $\mathrm{P}_{\mathrm{aO}_{2}} / \mathrm{F}_{\mathrm{IO}_{2}}>100 \mathrm{~mm} \mathrm{Hg}$ during the administration of NIV; a deterioration of 8 or more in consciousness, according to the Glasgow coma scale; hemodynamic instability (systolic arterial pressure of $<80 \mathrm{~mm} \mathrm{Hg}$ ); electrocardiogram showing signs of myocardial ischemia; intolerance to the technique (discomfort or claustrophobia); the inability to manage secretions adequately in spite of suction; respiratory acidosis $\left(\mathrm{pH}<7.3\right.$ with $\mathrm{P}_{\mathrm{CO}_{2}}$ $>55 \mathrm{~mm} \mathrm{Hg}$ ).

The decision to intubate a subject was always taken by a physician who was at the time applying the therapy, in accordance with the criteria mentioned above and standard procedure in a resuscitation unit. Following intubation, protective ventilation was applied to subjects with acute lung injury/ARDS, together with low tidal volumes, ele-

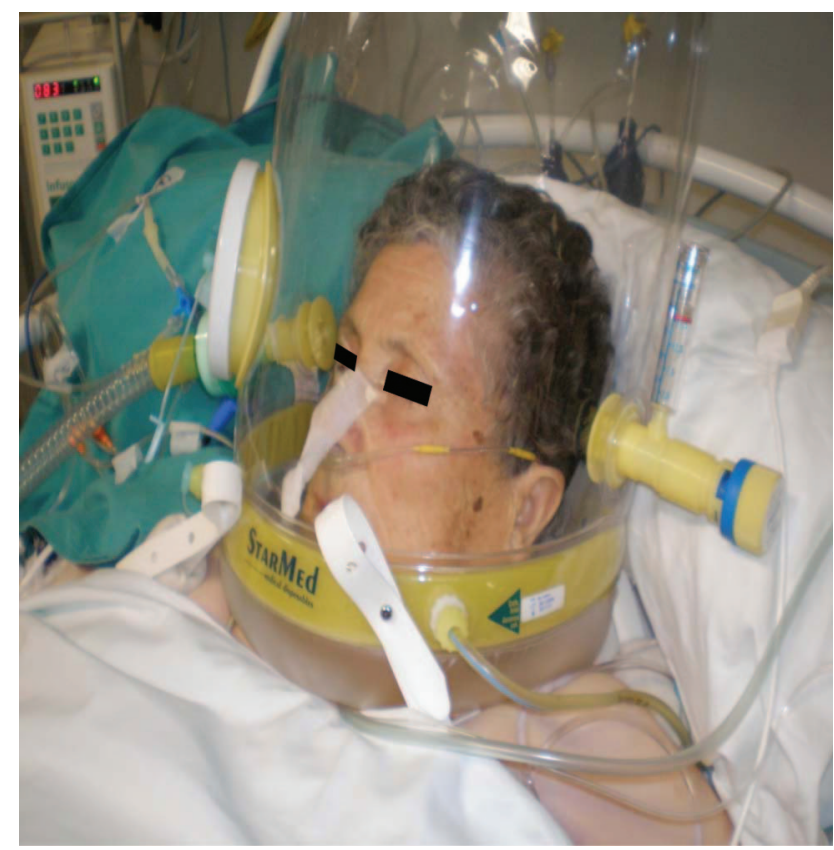

Fig. 2. Subject supported by helmet using noninvasive CPAP.

vated respiratory frequency, adequate PEEP to maintain $\mathrm{S}_{\mathrm{aO}_{2}}>90 \%$ or $\mathrm{P}_{\mathrm{aO}_{2}}>60 \mathrm{~mm} \mathrm{Hg}$, permissive hypercapnia, microbiological testing, an antibiotic therapy strategy, and the same protocols used in the unit for the process of extubation.

\section{Definition and Values}

Preoperative variables were collected, as follows: age, previous cardiopathy, a history of pulmonary pathology and obesity (body mass index $>30 \mathrm{~kg} / \mathrm{m}^{2}$ ), total proteins, albumin, transferrin and prealbumin, procalcitonin $(<0.5 \mathrm{ng} / \mathrm{dL}$ low probability of sepsis; $0.5-2 \mathrm{ng} / \mathrm{dL}$ high probability of sepsis; $2-10 \mathrm{ng} / \mathrm{dL}$ high risk of progression to severe sepsis; $>10 \mathrm{ng} / \mathrm{dL}$ severe sepsis), as well as hyperlactacidemia, and New York Heart Association and American Society of Anesthesiologists scores. Also, as to the length of time spent in surgery before resuscitation, the prognostic predictions made at the onset of resuscitation were recorded, as were Simplified Acute Physiology Score (SAPS) II and Sequential Organ Failure Assessment (SOFA) score, as well as the type of surgery. The causes of respiratory failure were also noted. Arterial blood gases $\left(\mathrm{P}_{\mathrm{aO}_{2}}, \mathrm{P}_{\mathrm{aCO}}, \mathrm{pH}, \mathrm{HCO}_{3}^{-}\right)$and hemodynamic (heart rate, respiratory rate and mean arterial pressure) parameters and $\mathrm{P}_{\mathrm{aO}_{2}} / \mathrm{F}_{\mathrm{IO}_{2}}$ were measured before the helmet was fitted, after 1 hour, 3 hours, 6 hours, 12 hours, 24 hours, 48 hours, whenever the subject's clinical condition required it, and at the end of the treatment.

The number of hours during which NIV was applied was also recorded, as were any complications that arose. If 
subjects had been intubated, the length of time they were intubated was recorded, as were any complications. In both groups, the length of time they stayed in the resuscitation unit and the hospital stay was recorded, as well as the place and cause of death.

The tolerance of NIV, from a period ranging from 1 hour after application to the end of its application, was recorded for all subjects. The scale of tolerance was divided as follows: very good, good, similar, worse, and markedly worse. If the subject required sedoanalgesia, a note was made of this, and the type used.

\section{Statistical Analysis}

Data are expressed for nominal variables as mean $\pm \mathrm{SD}$ for continuous variables. The comparisons of the qualitative variables between the 2 groups were performed using the Fisher exact test or the chi-square test. For quantitative variables, comparisons were performed using the independent Student $t$ test, or the Mann-Whitney $U$ test if the distribution of the continuous variables was not normal. The analysis was made with a nonparametric paired Wilcoxon test to compare data obtained before and after NIV for each patient. The variables that revealed a statistical difference and variables that were clinically relevant or important according to the scientific evidence available were analyzed using a multivariate analysis (logistic regression).

To confirm the model obtained (variables with the greatest association when predicting intubation in the population group used in our study), a receiver operating characteristic curve was drawn up, to prove the adjustment feasibility for that model. A $P$ value of $<.01$ was considered statistically significant. All statistical analyses were performed using statistical software (SPSS 11.0.1, SPSS, Chicago, Illinois).

\section{Results}

In the 2 years, 926 patients were admitted to the postsurgical critical care unit at Hospital General de Ciudad Real. Ninety-nine subjects were included prospectively in the study, due to their having presented with ARF in the postoperative phase, and having been initially treated with NIV using a helmet. Ten patients were not enrolled because they were simply intubated (see Fig. 1).

Of the 99 subjects treated with NIV, 74 did not require intubation $(74.7 \%)$. On being admitted to the resuscitation unit (Table 1), there were no significant differences between the subjects in the nonintubation and intubation groups, in terms of age, sex, comorbidity, New York Heart Association and American Society of Anesthesiologists scores, temperature, hemoglobin, and time spent in surgery. There were, however, significant differences in re-
Table 1. Characteristics of Both Groups Upon Admission to the Unit

\begin{tabular}{|c|c|c|c|}
\hline Characteristics & $\begin{array}{l}\text { Nonintubated } \\
\quad(n=74)\end{array}$ & $\begin{array}{l}\text { Intubated } \\
(n=25)\end{array}$ & $P$ \\
\hline Age, mean \pm SD y & $64.7 \pm 12.3$ & $63.6 \pm 16.1$ & .67 \\
\hline Male/female, no. & $12 / 8$ & $6 / 4$ & .81 \\
\hline Cardiac disease, no. (\%) & $14(70)$ & $6(56)$ & .32 \\
\hline Respiratory disease, no. (\%) & $9(43)$ & $5(48)$ & .53 \\
\hline \multicolumn{4}{|l|}{ NYHA Class, no. (\%) } \\
\hline I & $8(40)$ & $4(40)$ & .45 \\
\hline II & $9(47)$ & $4(40)$ & .56 \\
\hline III & $2(11)$ & $2(20)$ & .22 \\
\hline IV & $1(1)$ & 0 & .57 \\
\hline \multicolumn{4}{|l|}{ ASA Physical Status, no. (\%) } \\
\hline I & $1(5)$ & $1(10)$ & .39 \\
\hline II & $6(32)$ & $2(20)$ & .96 \\
\hline III & $12(60)$ & $5(50)$ & .18 \\
\hline IV & $1(5)$ & $2(20)$ & .08 \\
\hline Body temperature, mean $\pm \mathrm{SD}{ }^{\circ} \mathrm{C}$ & $37.0 \pm 0.5$ & $37.3 \pm 0.8$ & .34 \\
\hline Hemoglobin, mean $\pm \mathrm{SD}$ g/dL & $11.5 \pm 1.5$ & $11.2 \pm 1.8$ & .58 \\
\hline Surgery time, mean $\pm \mathrm{SD} h$ & $3.8 \pm 1.8$ & $4.8 \pm 2.3$ & .09 \\
\hline \multicolumn{4}{|l|}{ Little Malnutrition } \\
\hline Albumin, mean $\pm \mathrm{SD}$ g/dL & $2 \pm 7$ & $1 \pm 8$ & .71 \\
\hline Transferrin, mean $\pm \mathrm{SD} \mathrm{mg} / \mathrm{dL}$ & $1 \pm 3$ & 0 & .57 \\
\hline \multicolumn{4}{|l|}{ Moderate Malnutrition } \\
\hline Albumin, mean $\pm \mathrm{SD}$ g/dL & $18 \pm 58$ & $2 \pm 15$ & .10 \\
\hline Transferrin, mean $\pm \mathrm{SD}$ mg/dL & $15 \pm 48$ & $1 \pm 8$ & .07 \\
\hline \multicolumn{4}{|l|}{ Severe Malnutrition } \\
\hline Albumin, mean $\pm \mathrm{SD}$ g/dL & $11 \pm 36$ & $10 \pm 77$ & .005 \\
\hline Transferrin, mean $\pm \mathrm{SD} \mathrm{mg} / \mathrm{dL}$ & $14 \pm 45$ & $12 \pm 92$ & .008 \\
\hline SOFA score, median (IQR) & $4.1 \pm 1.5$ & $6.1 \pm 0.8$ & .03 \\
\hline SAPS II, median (IQR) & $50.2 \pm 14.6$ & $34.7 \pm 14.4$ & $<.001$ \\
\hline Lactic acid, mean $\pm \mathrm{SD} \mathrm{mg} / \mathrm{dL}$ & $13.1 \pm 7.6$ & $21.1 \pm 10.1$ & .001 \\
\hline \multicolumn{4}{|l|}{ Procalcitonin, no. (\%) } \\
\hline$<0.5 \mathrm{ng} / \mathrm{mL}$ & $47(64)$ & $3(12)$ & $<.001$ \\
\hline $0.5-2 \mathrm{ng} / \mathrm{mL}$ & $13(18)$ & $7(28)$ & .21 \\
\hline $2-5 \mathrm{ng} / \mathrm{mL}$ & $5(7)$ & $3(12)$ & .36 \\
\hline$>10 \mathrm{ng} / \mathrm{mL}$ & $9(12)$ & $12(48)$ & .003 \\
\hline
\end{tabular}

NYHA $=$ New York Heart Association classification of functional capacity and objective assessment

ASA $=$ American Society of Anesthesiologists physical status score

SOFA $=$ sequential organ failure assessment

SAPS $=$ simplified acute physiology score

lation to the state of the subjects' nutrition. The group of intubated subjects had significantly higher levels of moderate and serious malnutrition than the group of nonintubated subjects. There were also significant differences in relation to the severity of the illness, evaluated for both groups by means of SAPS II $(50.2 \pm 14.6$ vs $34.7 \pm 14.4$, $P<.001)$ and SOFA $(4.1 \pm 1.5$ vs $6.1 \pm 0.8, P=.03)$. Procalcitonin levels were statistically higher in the intubated group than in the nonintubated group, for each of the 4 levels of severity. Analyzing only for the presence of sepsis, the subjects were divided into 2 subgroups (procalcitonin $>$ or $<0.5 \mathrm{ng} / \mathrm{mL}$ ), and we observed that the 
Table 2. Ratio Between the Number of Patients in Both Groups, According to the Type of Surgery

\begin{tabular}{lccl}
\hline \hline \multicolumn{1}{c}{ Type of Surgery } & $\begin{array}{c}\text { Nonintubated } \\
(n=74)\end{array}$ & $\begin{array}{c}\text { Intubated } \\
(n=25)\end{array}$ & $P$ \\
\hline $\begin{array}{l}\text { Head and neck (neurosurgery, } \\
\text { maxillofacial, otorhinolaryngological }\end{array}$ & $9(12)$ & $3(12)$ & .95 \\
$\quad$ surgery) & & & \\
Esophagectomy + gastrectomy & $4(5)$ & 0 & .25 \\
Morbid obesity & $9(12)$ & $1(4)$ & .27 \\
Upper abdomen, other & $6(8)$ & $3(12)$ & .50 \\
Lower abdomen with peritonitis & $16(22)$ & $1(4)$ & .052 \\
Lower abdomen, no peritonitis & $17(23)$ & $10(40)$ & .07 \\
Aorto-bifemoral bypass & $1(1)$ & $4(16)$ & .003 \\
Multiple traumas & $3(4)$ & $1(4)$ & .97 \\
Thoracic surgery & $5(7)$ & $2(8)$ & .78 \\
Trauma surgery & $4(5)$ & 0 & .25 \\
\end{tabular}

Data are expressed as number and percent.

Table 3. Comparison of the Number of Patients in Both Groups, According to the Cause of the Acute Respiratory Failure

\begin{tabular}{lccc}
\hline \hline Cause of Acute Respiratory Failure & $\begin{array}{c}\text { Nonintubated } \\
(n=74)\end{array}$ & $\begin{array}{c}\text { Intubated } \\
(n=25)\end{array}$ & $P$ \\
\hline ARDS & $7(9)$ & $17(68)$ & $<.001$ \\
Acute Cardiogenic Pulmonary & & & \\
$\quad$ Edema & & & \\
$\quad$ Moderate & $12(16)$ & $2(8)$ & .35 \\
$\quad$ Severe & $7(9)$ & $2(8)$ & .88 \\
Pneumonia & $4(5)$ & $6(24)$ & .005 \\
Atelectasis & & & \\
$\quad$ Moderate & $19(26)$ & $2(8)$ & .046 \\
$\quad$ Severe & $25(34)$ & 0 & .001 \\
Pulmonary thromboembolism & $2(3)$ & 0 & .42 \\
Exacerbations of COPD & $3(4)$ & 0 & .32 \\
Pleural effusion & $1(1)$ & $1(4)$ & .39 \\
Pulmonary contusion & $1(1)$ & $1(4)$ & .39 \\
\end{tabular}

Data are expressed as number and percent.

nonintubated group had less sepsis than the intubated group, and that the differences were statistically different.

In relation to the type of surgery (Table 2), significant differences were found in the lower abdomen without peritonitis $(22 \%$ vs $4 \%, P=.052)$ and in aorto-bifemoral bypass ( $1 \%$ vs $16 \%, P=.003)$. The causes of ARF are shown in Table 3 . We observed significant differences between the 2 groups in terms of ARDS (9\% vs 68\%, $P<.001$ ), pneumonia (5\% vs $24 \%, P=.005$ ), moderate atelectasis (26\% vs $8 \%, P=.046)$, and severe atelectasis (34\% vs $0 \%, P=.001$ ). There were no significant differences in the remaining aetiologies.

The changes noted in physiological parameters (cardiac frequency, respiratory frequency, and mean arterial pres-
Table 4. Physiologic Parameters and Arterial Blood Gases Obtained Before and After NIV

\begin{tabular}{|c|c|c|c|}
\hline Variable & $\begin{array}{l}\text { Nonintubated } \\
\quad(n=74)\end{array}$ & $\begin{array}{l}\text { Intubated } \\
(n=25)\end{array}$ & $P$ \\
\hline \multicolumn{4}{|l|}{ Heart Rate, beats/min } \\
\hline Before NIV & $96.1 \pm 18.0$ & $96.1 \pm 17.2$ & .50 \\
\hline After NIV & $86.8 \pm 14.3$ & $89.7 \pm 14.0$ & .02 \\
\hline \multicolumn{4}{|c|}{ Respiratory Rate, breaths/min } \\
\hline Before NIV & $35.3 \pm 6.5$ & $38 \pm 7.9$ & .08 \\
\hline After NIV & $18.4 \pm 4.8$ & $30.8 \pm 7.8$ & $<.001$ \\
\hline \multicolumn{4}{|c|}{ Mean Arterial Pressure, $\mathrm{mm} \mathrm{Hg}$} \\
\hline Before NIV & $71.2 \pm 15.1$ & $72.7 \pm 14.7$ & .01 \\
\hline After NIV & $72.3 \pm 16.0$ & $73.1 \pm 12.4$ & .09 \\
\hline \multicolumn{4}{|l|}{$\mathrm{pH}$} \\
\hline Before NIV & $7.36 \pm 0.08$ & $7.33 \pm 0.1$ & .12 \\
\hline After NIV & $7.36 \pm 0.07$ & $7.34 \pm 0.08$ & .02 \\
\hline \multicolumn{4}{|l|}{$\mathrm{P}_{\mathrm{aO}_{2}}, \mathrm{~mm} \mathrm{Hg}$} \\
\hline Before NIV & $56.4 \pm 5.6$ & $54.9 \pm 9.8$ & .30 \\
\hline After NIV & $124.2 \pm 29.2$ & $77.9 \pm 23.8$ & $<.001$ \\
\hline \multicolumn{4}{|l|}{$\mathrm{P}_{\mathrm{aO}_{2}} / \mathrm{F}_{\mathrm{IO}_{2}}, \mathrm{~mm} \mathrm{Hg}$} \\
\hline Before NIV & $140.7 \pm 18.5$ & $131.4 \pm 26.5$ & .14 \\
\hline After NIV & $305.5 \pm 77.6$ & $170.0 \pm 71.8$ & $<.001$ \\
\hline \multicolumn{4}{|l|}{$\mathrm{P}_{\mathrm{aCO}_{2}}, \mathrm{~mm} \mathrm{Hg}$} \\
\hline Before NIV & $41.7 \pm 8.2$ & $39.4 \pm 7.5$ & .21 \\
\hline After NIV & $43.2 \pm 8.3$ & $42.4 \pm 8.3$ & .81 \\
\hline \multicolumn{4}{|l|}{$\mathrm{HCO}_{3}^{-}, \mathrm{mEq} / \mathrm{L}$} \\
\hline Before NIV & $25.6 \pm 6.1$ & $23.58 \pm 4.1$ & .01 \\
\hline After NIV & $25.9 \pm 5.1$ & $23.2 \pm 3.6$ & .02 \\
\hline $\begin{array}{l}\text { Data are expressed as mean } \\
\text { NIV = noninvasive ventilati }\end{array}$ & & & \\
\hline
\end{tabular}

sure) and arterial gasses before and after the application of NIV are shown in Table 4. The respiratory frequency in this initial period of 1 hour after the application of NIV reduced significantly in the nonintubated group $(35.3 \pm 6.5$ breaths/min vs $18.4 \pm 4.8$ breaths/min, $P<.001)$, and also reduced in the intubated group $(38 \pm 7.9$ vs $30.84 \pm 7.8$, $P=.002$ ).

In the nonintubated group, prior to the application of $\mathrm{NIV}$, the $\mathrm{P}_{\mathrm{aO}_{2}} / \mathrm{F}_{\mathrm{IO}_{2}}$ was slightly higher than in the intubated group, although this was not statistically significant $(140.7 \pm 18.5 \mathrm{~mm} \mathrm{Hg}$ vs $131.4 \pm 26.5 \mathrm{~mm} \mathrm{Hg}, P=.14)$. However, 1 hour after the application of NIV there was a significant increase in the $\mathrm{P}_{\mathrm{aO}_{2}} / \mathrm{F}_{\mathrm{IO}_{2}}$ in the nonintubated group $(140.5 \pm 18.5 \mathrm{~mm} \mathrm{Hg}$ vs $305.3 \pm 77.6 \mathrm{~mm} \mathrm{Hg}$, $P<.001)$, as compared with the intubated group (131.4 \pm 26.5 vs $170.0 \pm 71.8, P=.02)$ (Fig. 3).

At study entry, the 2 groups had similar $\mathrm{P}_{\mathrm{aCO}}$ $(41.7 \pm 8.2 \mathrm{~mm} \mathrm{Hg}$ vs $39.4 \pm 7.5 \mathrm{~mm} \mathrm{Hg}, P=.21)$ and $\mathrm{pH}(7.36 \pm 0.08$ vs $7.33 \pm 0.1, P=.12)$. One hour after the application of NIV, the $\mathrm{P}_{\mathrm{aCO}}$ increased slightly in the nonintubated group $(41.7 \pm 8.2 \mathrm{~mm} \mathrm{Hg}$ vs $43.2 \pm 8.3 \mathrm{~mm} \mathrm{Hg}, P=.07)$ and the intubated group 


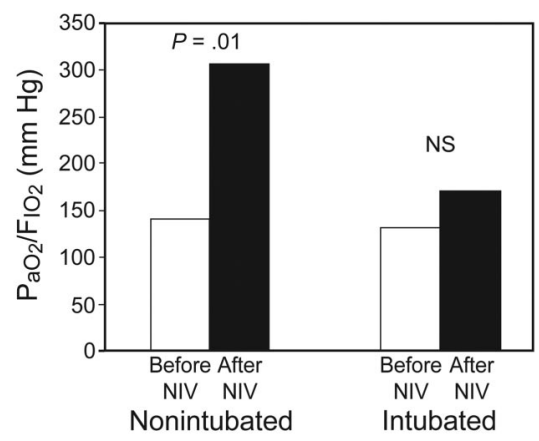

Fig. 3. $\mathrm{P}_{\mathrm{aO}_{2}} / \mathrm{F}_{1 \mathrm{O}_{2}}$ obtained before and after (noninvasive ventilation) NIV for both nonintubated and intubated groups. One hour after the application of NIV, the $\mathrm{P}_{\mathrm{aO}_{2}} / \mathrm{F}_{\mathrm{IO}_{2}}$ increased significantly only in the nonintubated group.

$(39.4 \pm 7.5 \mathrm{~mm} \mathrm{Hg}$ vs $42.4 \pm 8.3 \mathrm{~mm} \mathrm{Hg}, P=.051)$, although the difference was not statistically significant.

The average duration of NIV was $26.5 \pm 19.6$ hours in the nonintubated group. Of the 25 subjects for whom NIV was unsuccessful and who then required intubation, the average applicability of NIV was $15.4 \pm 28.9$ hours. Some $72 \%$ of subjects were intubated in the first 6 hours after the application of NIV.

A higher level of CPAP $\left(10.6 \pm 2.0 \mathrm{~cm} \mathrm{H}_{2} \mathrm{O}\right.$ vs $13.6 \pm 2.8 \mathrm{~cm} \mathrm{H}_{2} \mathrm{O}, P<.001$ ) was applied and higher $\mathrm{F}_{\mathrm{IO}_{2}}$ used $(0.41 \pm 0.03$ vs $0.48 \pm 0.07, P<.001)$ in the intubated subjects than in the nonintubated group, and in both cases the differences were statistically significant.

The only complication (Table 5) that had statistical significance was nosocomial pneumonia: no cases in the nonintubated group, as opposed to 3 cases (12\%) in the intubated group. The microbiological etiology of the pneumonia was established in the 3 subjects involved: 2 were methicillin-resistant Staphylococcus aureus and one was Pseudomonas aeruginosa.

The intubated group needed more sedation (52\%) than the nonintubated group (34\%) during NIV, although the difference was not statistically significant. The most-used form of sedation was remifentanil (62\%), followed by midazolam (26\%), morphine hydrochloride $(8 \%)$, and others $(4 \%)$.

The mean hospital stay $(12.7 \pm 8.2 \mathrm{~d}$ vs $30.2 \pm 20.1 \mathrm{~d}$, $P<.001)$ and time spent in the unit $(3.9 \pm 3.7 \mathrm{~d}$ vs $16.2 \pm 13.4 \mathrm{~d}, P<.001)$ of the nonintubated group were far shorter. This group also had significantly more in-unit deaths $(3 \%$ vs $40 \%, P<.001)$ and hospital deaths $(15 \%$ vs $44 \%, P=.004)$. Some $84 \%$ of subjects in the intubated group died during their hospital stay. The causes of death in the unit were mostly due to cases of multiple organ failure, secondary to sepsis. One of these was due to ischemic cardiopathy (acute coronary syndrome with ST elevation), and the other was due to massive pulmonary thromboembolism. Outside of the unit, the majority of deaths
Table 5. Characteristics of NIV Use and Outcome

\begin{tabular}{lccc}
\hline \hline & $\begin{array}{c}\text { Nonintubated } \\
(n=74)\end{array}$ & $\begin{array}{c}\text { Intubated } \\
(n=25)\end{array}$ & $P$ \\
\hline Total duration of NIV, min & $1,590 \pm 1,176$ & $924 \pm 1734$ & .001 \\
Total duration of NIV, h & $26.5 \pm 19.6$ & $15.4 \pm 28.9$ & .001 \\
CPAP level, cm $\mathrm{H}_{2} \mathrm{O}$ & $10.6 \pm 2.0$ & $13.6 \pm 2.8$ & $<.001$ \\
$\mathrm{~F}_{\mathrm{IO}}$ & $0.41 \pm 0.03$ & $0.48 \pm 0.07$ & $<.001$ \\
ICU stay, d & $3.9 \pm 3.7$ & $16.2 \pm 13.4$ & $<.001$ \\
Hospital stay, d & $12.7 \pm 8.2$ & $30.2 \pm 20.1$ & .001 \\
ICU mortality, no. (\%) & $2(3)$ & $10(40)$ & $<.001$ \\
Hospital mortality, no. (\%) & $11(15)$ & $11(44)$ & .004 \\
NIV complications, no. (\%) & $16(22)$ & $11(44)$ & .02 \\
Nosocomial pneumonia, no. (\%) & 0 & $3(12)$ & .002 \\
High temperature, no. (\%) & $6(8)$ & $1(4)$ & .52 \\
Noise, no. (\%) & $4(5)$ & 0 & .25 \\
Irritation ocular, no. (\%) & $4(5)$ & 0 & .25 \\
Gastric distension, no. $(\%)$ & $1(1)$ & 0 & .57 \\
Sedation, no. (\%) & $25(34)$ & $13(52)$ & .07 \\
& & & \\
\hline \pm values are mean \pm SD & & & \\
NIV = noninvasive ventilation & & & \\
\hline
\end{tabular}

were due to complications arising during surgery. Six subjects developed dehiscence with peritonitis, and intervention was required in some cases. All cases arose after the first week, 2 subjects developed respiratory insufficiency of unknown etiology, and 2 developed ischemic cardiopathy leading to subsequent death.

Once the variables (Table 6) with the greatest association when predicting intubation in the population group used in our study (the model obtained with 3 variables) had been obtained by means of the logistical regression, we find a total of 3 independent risk factors for unsuccessful NIV. The primary causes of respiratory failure are as follows: ARDS (odds ratio [OR] 18.34, 95\% CI 3.5195.74) and pneumonia (OR 31.84, 95\% CI 2.46-411.7), and, in second place, as a protective factor, is the increase in the $\mathrm{P}_{\mathrm{aO}_{2}} / \mathrm{F}_{\mathrm{IO}}$ after the first hour of NIV application (OR 0.97, 95\% CI 0.96-0.98). A receiver operating characteristic curve was drawn, to prove the adjustment feasibility for that model. It was observed that the area under the curve was $95.5 \%$, with a $95 \%$ CI of between $90.8 \%$ and $100 \%(P<.001)$, indicating that the said model with 3 variables predicted intubation in the group of people in our study with a high degree of sensitivity and specificity.

\section{Discussion}

Our study demonstrates the feasibility and clinical effectiveness of NIV (CPAP mode) using a helmet, in patients with ARF in the postoperative phase following different types of surgery. Fifteen percent of subjects developed acute hypoxic respiratory failure during their 
Table 6. Univariate and Multivariate Analysis of Risk Factors for the Failure of NIV

\begin{tabular}{|c|c|c|c|c|}
\hline Univariate Analysis Variable & Nonintubated & Intubated & Odds Ratio & $95 \% \mathrm{CI}$ \\
\hline SAPS II & $34.7 \pm 14.4$ & $50.2 \pm 14.6$ & 1.07 & $1.03-1.11$ \\
\hline SOFA & $4.1 \pm 1.5$ & $6.1 \pm 0.8$ & 1.77 & $1.33-2.34$ \\
\hline Surgery time, $\mathrm{h}$ & $3.8 \pm 1.8$ & $4.8 \pm 2.3$ & 1.25 & $1.00-1.54$ \\
\hline Lactic acid, mg/dL & $13.1 \pm 7.6$ & $21.1 \pm 10.1$ & 1.10 & $1.04-1.16$ \\
\hline Procalcitonin $>0.5 \mathrm{ng} / \mathrm{mL}, \%$ & 36.5 & 88.0 & 12.8 & $3.49-46.6$ \\
\hline ARDS, no. (\%) & $7(9)$ & $17(68)$ & 20.33 & $6.46-63.9$ \\
\hline Pneumonia, no. (\%) & $4(5)$ & $6(24)$ & 5.52 & $1.41-21.59$ \\
\hline Aorto-bifemoral bypass, no. (\%) & $1(1)$ & $4(16)$ & 13.9 & $1.47-131.1$ \\
\hline $\mathrm{P}_{\mathrm{aO}_{2}} / \mathrm{F}_{\mathrm{IO}_{2}}$, mean $\pm \mathrm{SD} \mathrm{mm} \mathrm{Hg}$ & $164.8 \pm 59.1$ & $37.62 \pm 46.4$ & 0.97 & $0.96-0.98$ \\
\hline $\begin{array}{l} \pm \text { values are } \pm \text { SD } \\
\text { SAPS }=\text { simplified acute physiology score } \\
\text { SOFA }=\text { sequential organ failure assessment } \\
\text { NIV }=\text { noninvasive ventilation }\end{array}$ & & & & \\
\hline
\end{tabular}

stay. In the study, NIV was applied in a prospective manner to 99 subjects. The incidence of severe hypoxemia found in our study was similar to the results in previous studies. ${ }^{38,29}$

The application of NIV was associated with an improvement of gaseous exchange and the prevention of intubation in $74.4 \%$ of subjects. In the multivariate analysis we identified pneumonia and ARDS as a cause of ARF, and a lack of improvement in the $\mathrm{P}_{\mathrm{aO}_{2}} / \mathrm{F}_{\mathrm{IO}_{2}}$ after the first hour of application of NIV as independent factors associated with unsuccessful NIV. In their study, Antonelli et al ${ }^{22}$ revealed similar results; $70 \%$ of subjects avoided intubation, with age over 40 years, ARDS, or pneumonia as a cause of ARF, a $\mathrm{P}_{\mathrm{aO}_{2}} / \mathrm{F}_{\mathrm{IO}_{2}}<146 \mathrm{~mm} \mathrm{Hg}$ after the first hour of application, and SAPS II $>35$ being independent factors leading to failure.

The role of NIV in hypoxemic ARF is getting more and more recognition in the literature. ${ }^{16,17,39,40}$ However, only a few studies from disciplines other than cardiothoracics ${ }^{41,42}$ have studied the feasibility and effectiveness of NIV in the postoperative phase, demonstrating that the improvement in gaseous exchange brought about by NIV could have repercussions on the need for intubation and mechanical ventilation in patients developing hypoxemia in the postoperative phase. ${ }^{43-46}$

Squadrone et $\mathrm{al}^{29}$ use CPAP mode in the treatment of postoperative hypoxemia in elective abdominal surgery, compared with the standard treatment with oxygen. They have concluded that CPAP may reduce the incidence of endotracheal intubation (1\% vs $10 \%$ ) and other serious complications in this type of patient. In this study, however, patients with $\mathrm{P}_{\mathrm{aO}_{2}} / \mathrm{F}_{\mathrm{IO}_{2}}<300 \mathrm{~mm} \mathrm{Hg}$ were recruited, previously excluding patients with ARDS criteria and including only patients in whom the cause of hypoxemia was postoperative atelectasis. ${ }^{47}$ In our study, subjects with ARDS criteria represented $24 \%$, of which a mere $30 \%$ avoided intubation and mechanical ventilation. Following the multivariate analysis, ARDS was the prediction factor for NIV (OR 18.34, 95\% CI 3.51-95.74).

Recently, in a large multicenter study, Antonelli et al ${ }^{48}$ assessed the use of NIV as the first line of action in ARDS, finding that intubation was avoided in 54\% of subjects. The group of subjects recruited was heterogeneous, and the vast majority of subjects were post-surgical. Furthermore, NIV was used in only $31 \%$ of subjects who developed ARDS. The atelectasis subgroup (46.4\%) showed a clear improvement when using CPAP, and intubation was avoided in $96 \%$ of these subjects. These were frequently diagnosed following abdominal surgery. ${ }^{49,50}$ Antonelli et $\mathrm{a}^{22}$ obtained similar results in the samples in the subgroup of subjects developing atelectasis, with a success rate of $68 \%$.

In our study, something similar happened in the subgroup for acute cardiogenic pulmonary edema (23\%), in which the success rate was $82.6 \%$. Numerous random studies ${ }^{19,39,51}$ suggested the use of NIV in CPAP mode, and with 2 pressure levels, for the treatment of acute cardiogenic pulmonary edema. In this study, $60 \%$ of subjects with pneumonia as a cause of ARF required intubation. Following the multivariate analysis, this proved to be an independent factor for unsuccessful NIV (OR 31.84, 95\% CI 2.46-411.7). The response to NIV in patients with pneumonia is not uniform. ${ }^{52-55}$

In our study, $10 \%$ of cases of nosocomial pneumonia were included as a cause of ARF, in which the technique had failed, and therefore endotracheal intubation was required in $60 \%$ of subjects, whereas Antonelli et al ${ }^{22}$ had obtained slightly lower percentages $(50 \%)$ in the 38 subjects with ARF secondary to pneumonia and acquired in the community. This was possibly influenced by the fact that the cases of pneumonia arose outside the hospital.

If we compare the intubated group with the nonintubated group, we observe that the $\mathrm{P}_{\mathrm{aO}_{2}} / \mathrm{F}_{\mathrm{IO}_{2}}$ is lower $(140.7 \pm 18.5 \mathrm{~mm} \mathrm{Hg}$ vs $131.4 \pm 26.5 \mathrm{~mm} \mathrm{Hg}, P=.14)$. 
After the first hour of application, the nonintubation group showed a significant statistical improvement in this ratio. Following the multivariate analysis, the $\mathrm{P}_{\mathrm{aO}_{2}} / \mathrm{F}_{\mathrm{IO}_{2}}$ in the first hour of application proved to be an independent prediction factor for the success of NIV (OR 0.97, 95\% CI 0.96-0.97).

The success rate of $74.4 \%$ is comparable with the rates published in the literature, in controlled and noncontrolled clinical studies alike, varying between $60 \%$ and $80 \%$ in hypoxemic ARF. ${ }^{20,29,56}$ However, in esophageal and gastric surgeries, the contraindications for the use of NIV tend to be taken into consideration, and certain studies ${ }^{29,56}$ have demonstrated that NIV can be used without adverse effects when the supporting pressure and/or the level of CPAP are $<12 \mathrm{~cm} \mathrm{H}_{2} \mathrm{O}$. Our study included 4 subjects who underwent esophagectomy and gastrectomy and developed hypoxemic ARF in the postoperative phase. A CPAP level of $10 \mathrm{~cm} \mathrm{H}_{2} \mathrm{O}$ was applied, for an average uninterrupted duration of 36 hours, without any complications arising or adverse effects being noted.

In previous studies the type of interface used was a limiting factor for the use of NIV for prolonged periods of time and was the cause of a large number of failures. ${ }^{17,57}$ In our study, due to the design of the interface, NIV was applied in cases of head and neck surgery. The feasibility of the use of NIV in the postoperative phase of trauma, head, and neck surgery has also been established in other recent studies. ${ }^{58}$

The helmet has recently been presented as an alternative to the facial interface, for the application of NIV..$^{59-62} \mathrm{We}$ found that there was less tolerance during the treatment, which was administered uninterrupted for more hours, and the incidence of necrosis of the skin, gastric distention, and eye irritation was higher. ${ }^{62,63}$ The use of the helmet might therefore explain the reduction in the incidence of intolerance $(2 \%)$, compared with the rate seen in other studies (14\%) in which cases NIV was applied using a facial interface..$^{57}$

NIV was applied continuously for an average of $26.5 \pm 19.6$ hours in the nonintubated group, and $15.4 \pm 28.9$ hours in the intubated group, although continuous, uninterrupted application differs, depending on the cause of respiratory failure. It is important to stress that the application of NIV did not exceed 72 hours in any of the subjects involved. The literature has only described such prolonged, uninterrupted usage in studies using the helmet. ${ }^{20,22,62}$ This might explain many of the beneficial results found in our subjects, in spite of the high severity rates presented.

$\mathrm{ARF}$ and nosocomial pneumonia arose as postoperative complications in the first week of postoperative care, in comparison with surgical reintervention and sepsis, which only tend to happen after more than 1 week. ${ }^{64,65}$ In our study, the 3 cases of nosocomial pneumonia arose in the first week after surgical intervention and in the intubated group. Antonelli et al ${ }^{22}$ described $28 \%$ with pneumonia in the intubated group, and only one of the 246 subjects in whom intubation was avoided. All of the results are similar to those described in the literature, and demonstrate that the use of NIV reduces the risk of infections of the respiratory tract. ${ }^{66-68}$ Recent studies have shown that atelectasis can encourage the growth of bacteria in the lung, giving rise to bacterial translocation to the blood and an increase in epithelial permeability. ${ }^{69,70}$ In our study using CPAP, we successfully resolved $96 \%$ of the incidence of atelectasis as a principal cause of respiratory failure. One of the greatest disadvantages to making conclusions from these and other published works stems from the diversity of diagnoses with which patients included in studies present, among them, acute cardiogenic pulmonary edema, pneumonia acquired in the community, patients with COPD, atelectasis, and ARDS with different etiologies.

The other problem is seen in patients undergoing NIV who need to be intubated due to the unfavorable progression of their condition. In effect, the mortality described for these patients is higher than the expected rate in a group of patients with ARF. Although this might express more the severity of the illness than a complication in the method, it is nevertheless important to highlight the possibility that a delay in intubation might, at least in part, be responsible for the patient's deterioration.

It is clear that doubts persist as to the value of NIV,71,72 and further studies are required in order to define properly the type of patient who might benefit from its use, and the type for whom a delay in the commencement of conventional mechanical ventilation would heighten the risk. However, it would seem to be clear that a group of post-surgical patients will benefit from the use of this noninvasive method.

There are inherent limitations to the study. We did not follow up on the subjects once they were released from hospital, and as a result we do not know the rate of mortality thereafter. This paper describes an observational and prospective study conducted in our daily clinic, without control subjects, and, as such, we are unable to conclude that the results seen in these subjects had been modified by the use of NIV, also taking into account the fact that neither of the groups are completely homogeneous in relation to certain variables, such as severity rates, the presence of septicemia, or lactacidemia. Nonetheless, the results obtained in our descriptive study could provide the basis for a wider study, one that is prospective, random, and compares NIV with conventional medical treatment.

\section{Conclusions}

NIV with a helmet should be considered as an interesting alternative to conventional ventilation in certain patients with hypoxemic ARF in the postoperative phase of 


\section{Helmet NIV in Patients With Acute Postoperative ARF}

different surgeries, including surgery of the head and neck, which are currently contraindications for the use of the technique.

\section{REFERENCES}

1. Lawrence V, Dhanda R, Hilsenbeck SG, Page CP. Risk of pulmonary complications after elective abdominal surgery. Chest 1996; 110(3):744-750

2. Warner DO. Preventing postoperative pulmonary complications: the role of the anesthesiologist. Anesthesiology 2000;92(5):1467-1472.

3. Brooks-Brunn JA. Predictors of postoperative pulmonary complications folowing abdominal surgery. Chest 1997;111(3):564-571.

4. Duggan M, Kavanagh BP. Pulmonary atelectasis: a pathogenic perioperative entity. Anesthesiology 2005;102(4):838-854.

5. Simonneau G, Vivien A, Sartene R, Kunstlinger F, Samaii K, Noviant I, Duroux P. Diaphragm dysfunction induced by upper abdominal surgery: role of postoperative pain. Am Rev Respir Dis 1983; 128(5):899-903

6. Dureuil B, Cantineau JP, Desmonts JM. Effects of upper or lower abdominal surgery on diaphragmatic function. Br J Anaesth 1987; 59(10):1230-1235.

7. Dureuil B, Virès N, Cantineau JP, Aubier M, Desmonts JM. Diapharagmatic contractility after abdominal surgery. J Appl Physiol 1986;61(5):1775-1780

8. Pansard JL, Mankikian B, Bertrand M, Kieffer E, Ciergue F, Viars P. Effects of thoracic extradural block on diaphragmatic electrical activity and contractility after upper abdominal surgery. Anesthesiology 1993;78(1):63-71.

9. Zwillich CW, Pierson DJ, Creagh CE, Sutton FD, Schactz E, Petty TL. Complications of assisted ventilation. A prospective study of 354 consecutive episodes. Am J Med 1974;57(2):161-170.

10. Colice GL, Stukel TA, Dain B. Laryngeal complications of prolonged intubacion. Chest 1989;96(4):877-884.

11. Stauffer JL. Complications of endotracheal intubation, tracheostomy, and artificial airways. Respir Care 1982;27(4):417-134.

12. Craven DE, Kunches LM, Kilinsky V Lichtenberg DA, Make BJ, McCabe WR. Risk factors for pneumonia and fatality in patients receiving continuous mechanical ventilation. Am Rev Respir Dis 1986;133(5):792-796.

13. Niederman MS, Ferranti RD, Zeigler A, Merrill WW, Reynolds HY. Respiratory infection complicating long-term traqueostomy: the implications of persistent gram negative tracheobronchial colonization. Chest 1984;85(1):39-44.

14. Stauffer JL. Complications and consequences of endotracheal intubation. Am J Med 1981;70:65-75.

15. Criner GJ, Tzouanakis A, Kreimer DT. Overview of improving tolerance of long-term mechanical ventilation. Crit Care Clin 1994; 10(4):845-866.

16. Organized jointly by the American Thoracic Society, the European Respiratory Society, the European Society of Intensive Care Medicine, and the Société de Réanimation de Langue Francaise, and approved by ATS Board of Directors, December 2000. International consensus conferences in intensive care medicine: noninvasive positive pressure ventilation in acute respiratory failure. Am J Respir Crit Care Med 2001;163(1):283-291.

17. Mehta S, Hill NS. Noninvasive ventilation. Am J Respir Crit Care Med 2001;163(2):540-577.

18. Brochard L, Isabey D, Piquet J, Amaro P, Mancebo J, Messadi AA, et al. Reversal of acute exacerbations of chronic obstructive lung disease by inspiratory assistance with a face mask. N Engl J Med 1990;323(22):1523-1530

19. Masip J, Betbese AJ, Paez J, Vecilla F, Cañizares R, Padró J, et al. Non-invasive pressure support ventilation versus conventional oxy- gen therapy in acute cardiogenic pulmonary oedema: a randomized trial. Lancet 2000;356(9248):2126-2132.

20. Antonelli M, Gonti G, Bufi M, Costa MG, Lappa A, Rocco M, et al. Noninvasive ventilation for treatment of acute respiratory failure in patients undergoing solid organ transplantation: a randomized trial. JAMA 2000;283(2):235-241.

21. Hilbert G, Gruson D, Vargas F, Valentino R, Gbikpi-Benissan G, Dupon M, et al. Noninvasive ventilation in inmunosppressed patients with pulmonary infiltrates, fever, and acute respiratory failure. $\mathrm{N}$ Engl J Med 2001;344(7):481-487.

22. Antonelli M, Conti G, Moro ML, Esquinas A, Gonzalez-Diaz G, Confalonieri M, et al. Predictors of failure of noninvasive positive pressure ventilation in patients with acute hypoxemic respiratory failure: a multi-center study. Intensive Care Med 2001;27(11):1718-28.

23. Girou E, Schortgen F, Declaux C, Brun-Buisson C, Blot F, Lefort Y, et al. Association of noninvasive ventilation with nosocomial infections and survival in critically ill patients. JAMA 2000;284(18): 2361-2367.

24. Girou E, Brun-Buisson C, Taillé S, Lemaire F, Brochard L. Secular trends in nosocomial infections and mortality associated with noninvasive ventilation in patients with exacerbation of COPD and pulmonary edema. JAMA 2003;290(22):2985-2991.

25. Domenighetti G, Gayer R, Gentilini R. Non-invasive pressure support ventilation in non-COPD patients with acute cardiogenic pulmonary oedema and severe community-acquired pneumonia: acute effects and outcome. Intensive Care Med 2002;28(9):1373-1378.

26. Peter JV, Moran JL, Phillips-Hughes J, Warn D. Noninvasive ventilation in acute respiratory failure. A metanalysis update. Crit Care Med 2002;30(3):555-562.

27. Auriant I, Jallot A, Hervé P, Cerrina J, Le Roy Ladurie F, et al. Noninvasive ventilation reduces mortality in acute respiratory failure following lung resection. Am J Respir Crit Care Med 2001;164(7): 1231-1235.

28. Jaber S, Delay JM, Chanques G, Sebbane M, Jacquet E, Souche B, et al. Outcomes of patients with acute respiratory failure after abdominal surgery treated with noninvasive positive pressure ventilation. Chest 2005;128(4):2688-2695.

29. Squadrone V, Coha M, Cerrutti E, Schellino MM, Biolino P, Occella $\mathrm{P}$, et al. Continous positive airway pressure for treatment of postoperative hypoxemia. JAMA 2005;293(5):589-595.

30. Stock MC, Dows JB, Gauer PK, Alster JM, Imrey PB. Prevention of postoperatory pulmonary complications with CPAP, incentive spirometry, and conservative therapy. Chest 1985;87(2):151-157.

31. Kindgen-Milles D, Buhl R, Gabriel A, Böhner H, Müller E. Nasal continuous positive airway pressure: a method to avoid endotracheal reintubation in postoperative high-risk patients with severe nonhypercapnic oxygenation failure. Chest 2000;117(4):1106-111.

32. Duncan SR, Negrin RS, Mihm FG, Guilleminault C, Raffin TA. Nasal continuous positive airway pressure in atelectasis. Chest 1987; 92(4):621-624.

33. Covelli HD, Weled BJ, Beekman JF. Efficacy of continuous positive airway pressure administered by facemask. Chest 1982;81(2):147-150.

34. Joris J, Sottiaux T, Chiche JD, Desaive CJ, Lamy ML. Effect of bi-level positive airway pressure (BiPAP) on the postoperative pulmonary restrictive syndrome in obese patients undergoing gastroplasty. Chest 1997;111(3):665-670.

35. Antonelli M, Conti G, Pelosi P, Gregoretti C, Pennisi MA, Costa R, et al. New treatment of acute hypoxemic respiratory failure: noninvasive pressure support ventilation delivered by helmet: a pilot controlled trial. Crit Care Med 2002;30(3):602-608.

36. Villa F. Evaluation of four noninvasive CPAP systems (abstract). Intensive Care Med 1999;Suppl 66:A246.

37. Bernard GR, Artigas A, Brigham KL, Carlet J, Falke K, Hudson L, et al. The American-European Consensus Conference on ARDS. 


\section{Helmet NIV in Patients With Acute Postoperative ARF}

Definitions, mechanisms, relevant outcomes, and clinical trial coordination. AM J Respir Crit Care Med 1994;149(3 Pt 1):818-824.

38. Moller JT, Wittrup M, Johansen SH. Hypoxemia in the postaesthesia care unit: an observer study. Anesthesiology 1990;73(5):890-895.

39. Bersten AD, Holt AW, Vedig AE, Skowronski GA, Gaggoley CJ. Treatment of severe cardiogenic pulmonary edema with continuous positive airway pressure delivered by face mask. N Engl J Med 1991;325(26): 1825-1830.

40. Kaneko Y, Floras JS, Usui K, Plante J, Tkacova R, Kubo T, et al. Cardiovascular effects of continuous positive airway pressure in patients with heart failure and obstructive sleep apnea. N Engl J Med 2003;348(13):1233-1241.

41. Perrin C, Julien V, Vénissac N, Berthier F, Padovani B, Guillot F, et al. Prophylactic use of noninvasive ventilation in patients undergoing lung resectional surgery. Respir Med 2007;101(7):1572-1578.

42. Aguiló, R, Togores B, Pons S, Rubí M, Barbé F, Agustí AG. Noninvasive ventilatory support after lung resectional surgery. Chest 1997;112(1):117-121.

43. Matte P, Jacquet L, Van Dyck M, Goenen M. Effects of conventional physiotherapy, continuous positive airway pressure and non-invasive ventilatory support with bilevel positive airway pressure after coronary artery bypass grafting. Acta Anaesthesiol Scand 2000;44(1):75-81.

44. Gust R, Gottschalk A, Schmidt H, Böttiger BW, Böhrer H, Martin E. Effects of continuous (CPAP) and bi-level positive airway pressure (BiPAP) on extravascular lung water after extubation of the trachea in patients following coronary artery bypass grafting. Intensive Care Med 1996;22(12):1345-1350.

45. Keenan SP. Noninvasive positive pressure ventilation in acute respiratory failure. JAMA 2000;284(18):2376-2378.

46. Pang D, Keenan SP, Cook DJ, Sibbald WJ. The effect of positive pressure airway support on mortality and the need for intubation in cardiogenic pulmonary edema. Chest 1998;114(4):1185-1192.

47. Hedenstierna G. Gas exchange during anaesthesia. Br J Anaesth 1990;64(4):507-514.

48. Antonelli M, Conti G, Esquinas A, Montini L, Maggiore SM, Bello $\mathrm{G}$, et al. A multiple-center survey on the use in clinical practice of noninvasive ventilation as a first-line intervention for acute respiratory distress syndrome. Crit Care Med 2007;35(1):18-25.

49. Becquemin J, Piquet J, Becquemin MH, Melliere D, Harf A. Pulmonary function after transverse or midline incision in patients with obstructive pulmonary disease. Intensive Care Med 1985;11(5):247251.

50. Siafakas N, Mitrouska I, Bouros D, et al. Surgery and the respiratory muscles. Thorax 1999;54(5):458-465.

51. Räsänen J, Heikkilä J, Downs J, Nikki P, Väisänen I, Viitanen A. Continuous positive airway pressure by face mask in acute cardiogenic pulmonary edema. Am J Cardiol 1985;55(4):296-300.

52. Confalonieri M, Potena A, Carbone G, Porta RD, Tolley EA, Umberto Meduri G. Acute respiratory failure in patients with severe community-acquired pneumonia. Am J Respir Crit Care Med 1999; 160(5 Pt 1):1585-1591.

53. Soo Hoo GW, Santiago S, Williams AJ. Nasal mechanical ventilation for hypercapnic respiratory failure in chronic obstructive pulmonary disease: determinants of success and failure. Crit Car Med 1994;22(8):1253-1261.

54. Menduri GU, Turner RE, Abou-Shala N, Wunderink R, Tolley E. Noninvasive positive pressure ventilation via face-mask: first-line intervention in patient with acute hypercapnic and hypoxemic respiratory failure. Chest 1996;109(1):179-193.

55. Wysocki M, Tric L, Wolff MA, Millet H, Herman B. Noninvasive pressure support ventilation in patients with acute respiratory failure. Chest 1995;107(3):761-768.

56. Gonti G, Cavaliere F, Costa R, Craba A, Cartarci S, Festa V, et al. Noninvasive positive-pressure ventilation with different interfaces in patients with respiratory failure after abdominal surgery: a matchedcontrol study. Respir Care 2007;52(12):1463-1471.

57. Delclaux C, L'Her E, Alberti C, Mancebo J, Abroug F, Gonti G, et al. Treatment of acute hypoxemic nonhypercapnic respiratory insufficiency with continuous positive airway pressure delivered by a face mask: a randomized controlled trial. JAMA 2000;284(18):2352-2360.

58. Battisti A, Michote JB, Tasaux D, van Gessel E, Jolliet P. Noninvasive ventilation in the recovery room for post-operative respiratory failure: a feasibility study. Swiss Med Wkly 2005;35(23-24): 339-343.

59. Chiumello D, Pelosi P, Carlesso E, Severgnini P, Aspesi M, Gamberoni $\mathrm{C}$, et al. Noninvasive positive pressure ventilation delivered by helmet vs standard face mask. Intensive Care Med 2003;29(10): 1671-1679.

60. Patroniti N, Foti G, Manfio A, Coppo A, Bellani G, Pesenti A. Head helmet versus face mask for non-invasive continuous positive airway pressure: a physiological study. Intensive Care Med 2003;29(10): 1680-1687.

61. Tonnelier JM, Prat G, Nowak E, Goetghebeur D, Renault A, Boles JM, L'Her E. Noninvasive continuous positive airway pressure ventilation using a new helmet interface: a case-control prospective pilot study. Intensive Care Med 2003;29(10):2077-2080.

62. Costa R, Navalesi P, Spinazzola G, Rossi M, Cavaliere F, Antonelli $\mathrm{M}$, et al. Comparative evaluation of different helmets on patientventilator interaction during noninvasive ventilation. Intensive Care Med 2008;34(6):1102-1108.

63. Antonelli M, Pennisi MA, Pelosi P, Gregoretti C, Squadrone V, Rocco M, et al. Non-invasive positive pressure ventilation using a helmet in patients with acute exacerbation of chronic obstructive pulmonary disease: a feasibility study. Anesthesiology 2004;100(1): 16-24.

64. Collins TC, Daley J, Henderson WH, Khuri SF. Risk factor for prolonged length of stay after major elective surgery. Ann Surg 1999;230(2):251-259.

65. O'Donohue WJ Jr. National survey of the usage of lung expansion modalities for the prevention and treatment of postoperative atelectasis following abdominal and thoracic surgery. Chest 1985;87(1):76-80.

66. Brochard L, Mancebo J, Wysocki M, Lofaso F, Conti G, Rauss A, et al. Noninvasive ventilation for acute exacerbations of chronic obstructive pulmonary disease. N Engl J Med 1995;333(13):817-822.

67. Nourdine K, Combes P, Carton MJ, Beuret P, Cannamela A, Ducreux JC. Does noninvasive ventilation reduce the ICU nosocomial infection risk? A prospective clinical survey. Intensive Care Med 1999;25(6):567-573.

68. Guérin C, Girard R, Chemorin C, De Varax R, Fournier G. Facial mask noninvasive mechanical ventilation on reduces the incidence of nosocomial pneumonia. A prospective epidemiological survey from a single ICU. Intensive Care Med 1997;23(10):1024-1032.

69. Van Kaam AH, Lachmann RA, Herting E, De Jaegere A, van Iwaarden F, Noorduyn LA, et al. Reducing atelectasis attenuates bacterial growth and translocation in experimental pneumonia. Am J Respir Crit Care Med 2004;169(9):1046-1053.

70. Duggan M, McCaul CL, McNamara PJ, Engelberts D, Ackerley C, Kavanagh BP. Atelectasis causes vascular leak and lethal ventricular failure in uninjured rat lungs. Am J Respir Crit Care Med 2003; 167(12):1633-1640.

71. Esteban A, Frutos-Vivar F, Ferguson N, Arabi Y, Apezteguía C, González M, et al. Noninvasive positive-pressure ventilation for respiratory failure after extubation. N Engl J Med 2004;350(24):24522460.

72. Keenan S, Powers C, McCormack D, Block G. Noninvasive positive pressure ventilation (NPPV) for post-extubation respiratory distress:a randomized controlled trial. JAMA 2002;287(24):32383244. 